\title{
Shakespeare's Othello: The Esteemed, Reviled, Shunned, and Integrated?
}

\author{
Dr Rachelle D. Harris \\ Visiting Professor \\ Frontier International Academy \\ University of the District of Columbia \\ United States of America \\ volvo111272@gmail.com
}

\begin{abstract}
In Shakespearean literature, one can find themes that challenge the Elizabethan conventional way of thinking and life, and the tragedy of Othello is no exception. In a dramatic presentation, Shakespeare challenges the way in which Black people are seen in Elizabethan society by placing a Moor in the context of Venice, Italy who is both hated and respected in his place in a racist society. There is no doubt that there is racism in Elizabethan society. According to Eldred Jones, during the era in which Othello is composed, Queen Elizabeth enacts legislation that calls for all Black people to leave the country (Jones, 1994). Racism is not the core theme of the dramatic piece; however, the existence of racism is illustrated and expressed via Shakespeare's artistic medium. Just as feminism, greed, jealousy, hubris, and varying other matters dealing with the human spirit do not seepage Shakespeare's consideration, nor do race matters. Furthermore, just as he dramatizes human issues, he dramatizes race matters. There are fictional elements in
\end{abstract}


Othello that are intertwined with nonfictional matters of human behavior and racial unrest. In the middle of racial unrest, Shakespeare composes a theatrical production with a Black character who is esteemed, reviled, shunned, and integrated into such a society, capturing the complicated nature of communal racism itself.

Keywords: Shakespeare, Othello, Integration, Racism

\section{Section 1.0}

Othello is a dramatic piece that presents race in a problematic light which is worth noting because the original play, Cinthio, explores the interaction between Iago's equal, Ensign, and the Moor as being rooted in jealosy. The Moor's race is not mentioned in the orgininal text (Bloom, 1987). In Cinthio, Ensign falls in love with the Moor's wife and tries to win her affections. When this does not work, he elects to call her fidelity into question and embarks on a plan to break the Moor and Desdemona apart; however, Ensign never references the Moor's race. Although the manner in which Ensign renders the Captain and Desdemona's loyalty to the Moor in question, the primary focus of his drudgery rests with the fact that he loves Desdemona and with her being too enthralled with her husband to notice, not asserting any underlying hate or belief that the Moor should hold an inferior position to his own. This is important because writers often focus on the matters that are relevant to their times even when composing fictional pieces. Snyder goes on to state that when placed against the backdrop of the original story, it is interesting at the least that Shakespeare elects to strongly impart the problematic terms of race and skin color in Othello (Bloom, 1987). This problematic undertaking in the middle of an era where racial protests do not align with those of the $19^{\text {th }}$ and $20^{\text {th }}$ century is even more interesting because it means that 
Shakespeare is a literary activist. He brings questions to light that scrutinize the status of interracial interaction at a time when inquisition is not often permitted.

\section{Section 1.1}

Stephen Greenblatt posits that skin color is without a doubt impacting of Othello's enduring prominence of interloper status in Othello (Bloom, 1987). Implementing the problematic race aspect in the text illustrates the complicated nature of communal racism during the Shakespearean era. Michael Bristol further recognizes the nature of racism in the Shakespearean era by noting that racism in Shakespeare's time was on a different plane when compared to the present; however, he also notes that racism most certainly was evident in the broad range in the contexts of frame of mind and outlook (1996). The fact that Othello is so focused on race matters is either telling of Shakespeare's personal beliefs or of his personal experiences in the society in which he resided. In many of his plays, Shakespeare's art is reflective of societal beliefs or critical of the current culture. Given this aspect of predominance in his art, one ventures to say that he employs Othello as a catalyst to lay out the current perspectives of the day regarding race matters.

Section 2.0

In addition to the problematic incorporation of race matters in Othello, Shakespeare aligns the communal attitudes of the day in Venice, Italy with the play's social construction. For instance, Moors do coincide with Venetians; however, Moors are the sectional representation within the community, and they are illustrated by noticeable differences within the society. Furthermore, with regards to actual historical racial interaction, the Venetian society does 
demonstrate obvious racial bias against other groups such as Jewish people; hence, the social division with regards to race in the Merchant of Venice also reflects discriminatory practices with regards to other groups based on race and even further religion (Wilders 232). White people are the majority within the construction of Venetian society. Because Shakespeare creates a piece in Othello that is a reflection of Venetian society, the perspectives that are conveyed about Othello's race are commonplace for the time period. For instance, Rodrigo expresses contempt for Othello with heated racist comments: "What a full fortune does the thicklips owe/If he can carry't thus!" (1.1.67-68). Here Rodrigo is upset with Othello's position and marriage to Desdemona; however, he does not attack his character to illustrate his disapproval. Instead, Rodrigo attacks Othello's physical appearance. Although Rodrigo is jealous of Othello to some degree, he does not express that jealousy by finding fault with Othello's actual character. In other words, his contemptuous comments rest with Othello's appearance and the fact that Desdemona elects to convey her love for Othello, not his physical characteristics. This is evidence that Othello is also reviled in the community for his position and for his marriage to Desdemona which has occurred regardless of his ethnic appearance.

\section{Section 2.1 Racialism}

Rodrigo expresses disdain for Othello based on racialism in his attack on Othello's physical features. The expression of racialism is distinctly different from racism; however, racialism or the belief that one is inferior based on his or her physical features is a gateway to racism. According to Tzvetan Todorov, there is a difference between racialism and racism. He references racialism as the acceptance that there are assemblages of people with similar corporeal features. The acceptance of racialism is devoid of racial preconceptions. Generally, this 
perspective is accepted as a scientific view. In relation to racialism, Todorov notes that racialism has the potential to develop into racism which is altogether different because it encompasses the view that corporeal features place one race of people in superior positions over others. Furthermore, he notes that racism that stems from racialism harvests calamitous fallouts (p. 64-65). The calamitous fallout is blatantly apparent in Othello with Desdamona and Othello's deaths. Iago focuses on racialism to set forth plans that lead to human destruction.

Section 2.2 Intrinsic and Extrinsic Racism

Kwame Appiah concurs with Todorov's assertions about racialism; however, he makes a distinction between types of racism, intrinsic and extrinsic. Intrinsic racism asserts that different races possess varying moral capabilities, and the darker the skin, the lower one's moral capabilities; whereas, extrinsic racism asserts that certain races of people deserve to be treated in discriminatory manners because their skin colors render them lacking in moral capabilities and, therefore, deserving of differing treatment (5-12). Of course, Shakespeare does not have knowledge of these theoretical perspectives with regards to race when he composes Othello; however, he does cover both intrinsic and extrinsic racism. For instance, Rodrigo's apparent disdain for Othello is rooted in intrinsic racism, for he cannot fathom that Desdemona would elect to marry Othello because he does not believe that Othello's physical features are comparable to his own due to his perceived European superiority. Iago and Rodrigo both express instances of intrinsic racism in their speech that allows them to cross over into extrinsic racism. The comradery between Iago and Rodrigo is based on intrinsic racism, and their actions are based on extrinsic racism. When Iago says, "Her eye must be fed;/and what delight shall she have to look on the devil? When the blood is made dull with the act of/sport, there should be, 
again to inflame it and to" (2.1.226-29) and further states, "very nature will/instruct her in it and compel her to some second choice" (2.1.235-36), he makes reference to Othello's appearance as being devilish. Furthermore, he implies that Desdemona's interest in Othello is rooted in a sexual nature as opposed to genuine love. He also goes on to state that nature will compel her to make another choice when the sexual novelty wears off. By comparing Othello to the devil, Iago is illustrating extrinsic racism, for he equates Othello with the devil based on nothing other than his physical appearance. Comparing Othello to the devil implies that he lacks certain moral capabilities because of his race which gives the impression that Othello is deserving of the treatment he receives from Iago because of his racial makeup. By illustrating both intrinsic and extrinsic racism, Iago and Rodrigo work to emit the complicated nature of racism in the Shakespearean era.

\subsection{Racism's Impact on Othello's Self-Perspective}

With the complicated components of racism that Shakespeare composes in Othello with regards to its intrinsic and extrinsic nature, the racism in the text is even further complexified because of the impact it has on Othello. For example, Iago's view of Othello actually works to poison Othello's self-perspective. According to Robert Hornback, "the "horrid" potential of the normative humor so prevalent in the period (e.g., in laughter at natural fools, cockold jokes, ethnic jokes or put-down jo-kes generally), which always defines or bolsters social norms at the expense of the transgressive or merely different and thereby makes his audience disgustingly complicit in Iago's jeering sadism” is apparent in Othello (Hornback). According to Janet Adelman, Othello's position in Venice lends itself to his victimization in regards to "the racist ideology everywhere visible in Venice, an ideology to which he is relentlessly subjected and 
which increasingly comes to define him as he internalizes it" (125). In the play, Iago's racist views poison Othello's self-perspective. Iago tells Othello that Desdemona compares him to White men, and she now regrets her decision to marry him when looking at him in the light of so called greater men: "Her will, recoiling to her better judgment,/May fall to match you with her country forms/and happily repent" (3.3.236-38). Although Othello is not inferior, he now develops the understanding that Desdemona betrays him because she sees him as inferior. This is not something that Othello is used to, and he reacts with anger and rage because he now sees himself as some others see him. Othello leaves a born position of prominence in Africa in order to serve in the Venetian military. He goes to live in the Venetian community to make his own way in life without being automatically revered as he would in his own community due to his royal status; however, he does not know racism before coming to the Venetian society. Even among the racist perspectives in the Venetian community, he experiences aspects of free integration in his relationship with Desdamona and in his position as general with the Venetians. Regardless of his accomplishments, there are still those who harbor resentment for Othello. Rodrigo shares hatred for Othello along with Iago. He expresses this hatred by using racial slurs such as the one mentioned earlier. Initially, it appears as though Iago expresses hate for Othello because of his belief that Othello has slept with his wife; however, he later comments that Othello does not deserve to be in a position that sets superior to his own in Venetian society; "We cannot all be masters, nor all masters/Cannot be truly follow'd" (1.1.44-45). The initiation of Othello's poisoned self-perspective begins with Brabantio's lines “Look to her Moor, if thou hast eyes to see:/She has deceived her father, and may thee" (1.3.294-95). With all that occurs before this statement, it is apparent that Brabantio's ire does not truly rest with the fact that Desdemona has deceived him but with the fact that she has openly ventured to marry a Black 
man. This statement also serves as a wake-up call for Othello in that he knows that he openly enjoys fellowship with Brabantio at his home before he marries his daughter. After marrying his daughter, Othello finds that the admiration that Brabantio has for him in regards to being a commander in the Venetian Army is not without limits, and these limits are connected with Othello staying in his social place and not mixing with White women. This is further evidence of how Othello is esteemed, reviled, and shunned in Venetian society, an extended illustration of the complicated nature of communal racism.

\subsection{Societal Stereotypes of the Black Male Taking the White Female by Force}

The components of racism are complicated in Othello since he is such a respected commander in the Venetian Army. One may wonder how Othello can be so respected in one sense and so hated in another. The demonization that Othello endures in Venetian society is a characteristic that works in his favor as a commander in the army, but it works against him in his social interactions. Othello is compared to the devil in an earlier passage, and Brabantio asserts that Othello must have enacted some type of black magic on Desdemona to get her to fall in love with him. This explanation emerges after Iago reminds Brabantio that he is a senator and of how the nature of their relationship will appear to society. Iago and Rodrigo succeed in arousing Desdemona's father's anger by simply mentioning the racial difference between Desdemona and Othello. Observe Iago's comment to Brabantio regarding the relationship: “An old black ram/Is tupping your white ewe" (1.1.89-90). Furthermore, Iago and Roderigo plant the implication that Desdemona's children would end up being biracial. They further emphasize to Brabantio that he will suffer societal mimicry and humiliation if such an event occurs: "You'll have your daughter covered with a Barbary/Horse; you'll have your nephews neigh to you; you'll have cours-/ers for 
cousins and gennets for germans" (1.1.111-14). As opposed to accepting that his daughter chose Othello as her partner, Brabantio elects to come up with a cover story, stating that Othello took his daughter by force and roots. This is because he needs to save political face in his society. Observe Brabantio's plea to Rodrigo for affirmation of such an explanation: "Is there not charms/By which the property of youth and maidhood/May be abused? Have you not read, Roderigo,/Of some such thing?" (1.1.171-74). This comes after Iago's reminder that he is a senator; observe:

IAGO: $\quad$ I am one, sir, that comes to tell you your daughter and the Moor are now making the beast with two backs.

BRABANTIO: $\quad$ Thou art a villain.

IAGO: $\quad$ You are--a senator. (1.1.116-119)

Brabantio needs an explanation as to why his daughter would fall in love with Othello. He cannot accept that this is simply a choice that she has made out of matters of the heart, and he explores the option of some dark sorcery being imparted upon Desdemona as an explanation for her behavior. Observe:

BRABANTIO: $\quad$ Ay, to me;

She is abused, stol'n from me, and corrupted

By spells and medicines bought of mountebanks;

For nature so preposterously to err,

Being not deficient, blind, or lame of sense, 
Sans witchcraft could not. (1.3.61-66)

Here, again Othello is aligned with some devilish nature of existence. Othello's demonization is even further apparent in Emelia's reaction after he kills Desdemona. Observe: “O, the more angel she,/And you the blacker devil!" (5.2.132-33). Of course, Othello commits an unforgivable act with taking Desdemona's life; however, the fact that the act is equated with his skin color is further evidence of his demonization in relation to race and more evidence of his reviled status in terms of social interaction.

Even among racist societal perspectives, Othello enjoys a reverence in the community, and he uses this reverence to negotiate Barbantio's now tainted perspective on race. Othello brings the past to Brabantio's attention in order to get him to see past the societal scorn that he may endure with Othello and Desdemona's union: “Her father loved me; oft invited me;/Still question'd me the story of my life,/From year to year, the battles, sieges, fortunes,/That I have passed (1.3.130-33). There is a complicated component to Desdemona and Othello's relationship, for Othello holds a somewhat esteemed position in relation to Desdemona regardless of his race. This contributes to the argument that Othello is accepted in society in some senses and shunned in others. The Duke of Venice tells Brabantio that Othello if a righteous man regardless of his color: "If virtue no delighted beauty lack/Your son-in-law is far more fair than black" (1.3.292-93). This enhances the perspective that Othello is accepted in some respects; however, this statement also further illustrates the racism that is apparent in Venetian society in the context of the play, for the Duke equates a negative connotation with being Black in stating that Othello is more fair than Black. In other words, Othello is Black, but 
he is different than the average Black, a twisted perspective that is even apparent in racist views in 2017.

\subsection{Female Subservience Trumps the "Race Card"}

The negativity that is associated with being Black is something that Desdemona's character recognizes as well, and she utilizes her knowledge of societal constraints and prejudice to defend Othello's position when he is accused of bewitching her in order to gain her love. According to Emily Bartels, Desdemona employs her knowledge of Venetian society to maneuver around societal constraints in covering her interracial marriage with social morals in terms of a woman's duty to her husband by "Paying due respect to her "noble father" (I.iii.180), she acknowledges that she is "bound" to him "for life and education" (I.iii.182), that he is "the lord of duty" (I.iii.184), and that she is "hitherto [his] daughter" (I.iii.185). She then insists that her marriage fulfills her "duty" to turn from father to husband, as daughters must and as her mother did, "preferring [Brabantio] before her father" (I.iii.187). Significantly, in aligning herself with her mother, she strategically glosses over two factors that make her own marriage radically different and socially taboo" (425). When faced with such an argument, Brabantio is left without a choice but to abandon his racist line of questioning to adhere to the societal standard that a woman has a duty to her father initially; however, once she is married, her duty is to her husband. This is an illustration of Othello's integration into Venetian society; however, this integration is manifested upon him begrudgingly in order to pay precedent to a woman being subservient to a man.

There is an opposing view that the true purpose of Othello is not to illustrate racism towards Black men but to punish White women. Celia Daileader describes Othellophilia in 
"Racism, Misogyny, and the Othello Myth" as a means of punishing White women. In the article, Blackchild and Daileader assert that Othello is the initial document in English fiction that explores the "European racial conscious - ness" (2008, p.102). However, Daileader does not overlook the racist elements in Othello. In fact, she eventually concludes that racism and the oppression of female sexuality have a dual existence in the play, but in the same breath, she asserts that the villainization of the Black man as a devil with an enormous penis is not a new concept with the advent of Othello (Blackchild et. al, 2008). As convincing as their argument is, there is the perspective that the authors actually contribute to stereotyping the Black male with their assertions about large penises penetrating White women before Shakespeare's Othello. Blackchild and Daileader actually utilize a stereotype as a precursor to ask why Othello is not focused on domestic violence as opposed to racism; however, with their protest that Othello is a play that addresses the impact of racism as opposed to domestic violence, they actually support the claim that Othello is a study in racists perspectives in Venetian society.

\subsection{Conclusion}

The apparent racism in Othello is portrayed as a normal part of everyday Elizabethan society. During this era, Black people are often equated with savagery. Iago uses this seemingly uniform perception to manipulate Barbantio into illustrating a racist depiction of how Desdemona and Othello's marriage manifests. Against a social backdrop that portrays Black men as being savages, Shakespeare creates a character who is both revered and scorned in Elizabethan society. Iago exploits these preconceptions regarding race in order to plant a seed of inferior self-perception within Othello in order to fertilize a tragic outcome. In fostering this tragic outcome, he provides society with the perception of having evidence of the savagery of 
Black men. This is a situation that makes for social mending between racial groups because a complete picture of social misconceptions and racially-based manipulation is presented to the audience. 


\section{References}

Adelman, J. (1997). Iagos alter ego: Race as projection in othello. Shakespeare Quarterly,48(2),125. doi:10.2307/2871277

Appiah, K. A. (1990). Racisms. In D.T. Goldberg (Ed.), Anatomy of racism (pp. 3- 17). Minneapolis: University of Minnesota Publishers.

Bartels, E. C. (1996). Strategies of submission: Desdemona, the duchess, and the assertion of desire. Studies in English Literature, 36(2), 417-433.

Blackchild, F., \& Daileader, C. R. (2008). Racism, misogyny, and the Othello myth. New Theatre Quarterly, 24(1), 102-103.

Greenblatt, S. (1987). The Improvisation of Power. In H. Bloom (Ed.), William shakespeare's othello. modern critical interpretations (pp. 37-60). New York \& Philadelphia: Chelsea House Publishers.

Snyder, S. (1987). Beyond Comedy: Othello. In H. Bloom (Ed.), William Shakespeare's Othello. Modern Critical Interpretations (pp. 23-36). New York \& Philadelphia: Chelsea House Publishers.

Bristol, M.D. (1996). Big-Time Shakespeare. London \& New York: Routledge.

Hornback, R. (2001). Emblems of folly in the first othello: Renaissance blackface, moor's coat, and muckender. Comparative Drama, (35)1, 69-99.

Jones, E. (1994). Othello-An Interpretation. In A.G. Barthelemy (Ed.), Critical essays on shakespeare's othello (pp. 39-55). Barthelemy Pub. Macmillan New York, NY.

Shakespeare, W. (1997). Othello. University of Victoria. Web. 17 July. 2017.

Todorov, T. (2000). Race and Racism. Trans. C. Porter. Theories of race and racism (pp. 6470). In L. Back \& J. Solomos. London \& New York: Routledge. 
Wilders, J. (Ed.). (1969). Shakespeare: The merchant of venice. London: Macmillan. 